\title{
Castration and Reproductive Behavior in the Paradise Fish, Macropodus opercularis (L.) (Osteichthyes: Belontiidae)
}

\author{
T. A. VILLARS ${ }^{1}$ AND R. E. DAVIS \\ Department of Psychology and The Neurosciences Laboratory. The University of Michigan, \\ Ann Arbor, MI 48109
}

(Received 4 February 1977)

\begin{abstract}
VILLARS, T. A. AND R. E. DAVIS. Castration and reproductive behavior in the paradise fish, Macropodus opercularis (L.) Osteich thyes: Belontiidae. PHYSIOL. BEHAV. 19(3) 371-375, 1977. - The effects of castration on male spawning behavior, nestbuilding and fertility were measured in a five day spawning trial with an in tact female. Spawning and fertility decreased one week following castration while nestbuilding was unaffected. Sham operated males showed normal spawning and fertility. Two weeks postoperatively, fertility and spawning were increased paralleling partial regeneration of the testes. The antigonadotropin methallibure blocked testes regeneration and recovery of spawning in castrated males but it had no effect on reproductive functions of intact males. Spawning did not decrease in one-week castrated males which were administered testosterone enathanate. The results suggest that gonadal androgen facilitates sexual behavior in Macropodus.
\end{abstract}

Castration Testosterone Methallibure Fish sexual behavior

HORMONAL control of fish reproductive behavior has not been extensively investigated. Gonadal hormones participate in the differentiation and maintenance of secondary sex characteristics [29] but the function of gonadal hormones in the activation and maintenance of sex behavior is controversial. Castration decreased sexual behavior in male Gasterosteus, Salmo, Xiphophorus and Cymatogaster [19]. Replacement therapy with methyl testosterone reversed the effects of castration in male Gasterosteus. In contrast, castration had no effects on reproductive behavior of the cichlid Hemichromis and the anabantid Betta, and the sexual activity of male Bathygobius was increased. Trichogaster. showed marked individual differences in response to castration $[19,14]$.

The present study examined the effects of castration and testosterone administration on sexual behavior of the anabantid Macropodus opercularis, the paradise fish. Previous studies suggested that Macropodus is not dependent on gonadal androgen for the maintenance of sexual behavior. Davis, Mitchell and Dolson [6] demonstrated testicular atrophy in males which received the antigonadotropic agent methallibure for five weeks, but the sexual behavior of the males appeared normal. The males did not receive methallibure during the spawning trial, and testicular functions could have recovered. Other males castrated two weeks prior to a spawning trial and reoperated prior to successive trials continued to show normal sexual behavior and only slightly reduced fertility [27]. Examination four weeks after the last operation revealed that substantial testicular regeneration had occurred.

The present investigation consisted of three parts. First, the effects of castration on sexual behavior one week and two weeks following the operation were determined. Second, the effects on sexual behavior of castration plus methallibure administration were examined. Finally, the behavioral effects of testosterone replacement were investigated.

\section{METHOD}

Adult paradise fish, Macropodus opercularis (Osteichthyes: Belontiidae), $4.2 \mathrm{~g}$ mean body weight, were obtained from Gossington Tropical Fishes, Del Ray Beach, FL, or from a local dealer of Florida stock. Fish were kept in 190 liter community tanks for at least seven days before an experiment, and cared for as previously described [4].

\section{Surgery}

Fish were anesthetized with Finquel (Ayerst), weighed and placed on a cool damp platform. An incision was made into the caudal end of the body cavity just dorsal of the urogenital papilla (Fig. 1). The incision was extended dorsally to visualize the distal end of the ipsilateral testes which was then freed from the supporting messentery and lifted out. The contralateral lobe was similarly removed through the same opening. The testes were weighed and a

\footnotetext{
'Present address: Department of Psychology, St. Mary's College, Notre Dame, IN 46556.
} 


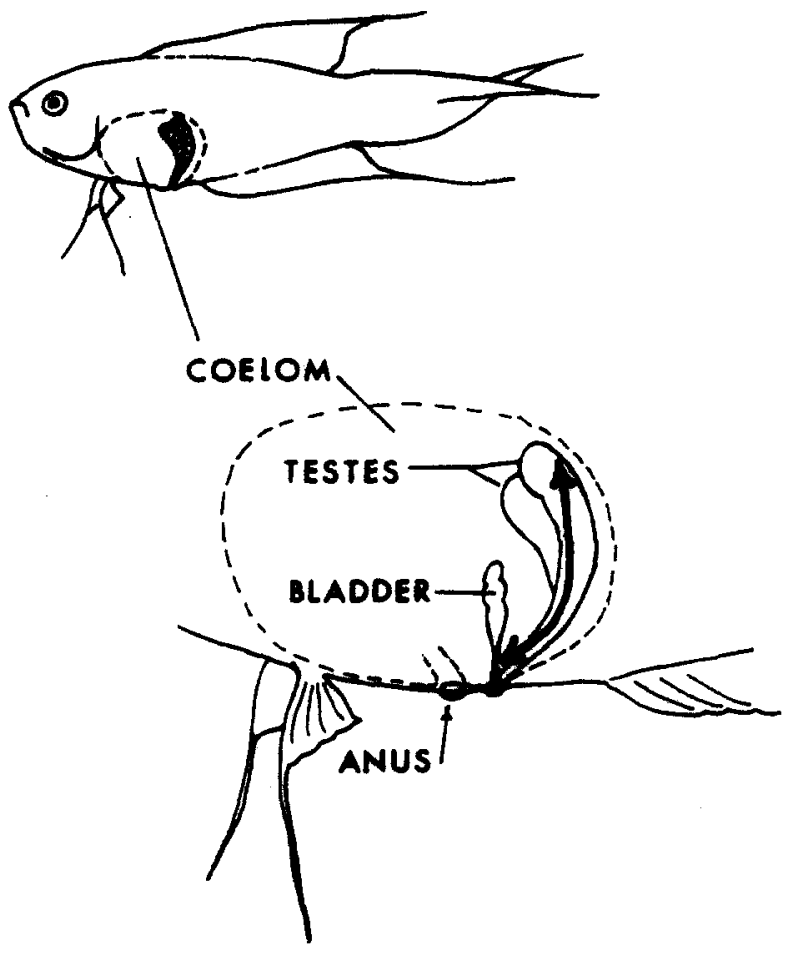

FIG. 1. Illustration of the location of the testes in the coelom and the incision used in the castration procedure.

pretrial gonadosomatic index, G.S.I., was determined as the (testes $w t /$ body wt) $\times 100$. The wound was closed with silk cardiovascular thread (Deknatel). Sutures were removed two or three days later. In the sham operation the tests were manipulated then the wound closed. Between surgery and the trial fish were kept in individual, 9 liter isolation tanks.

\section{Drugs}

Methallibure (I.C.I., 33,828) was administered perorally, mixed with the standard diet in a concentration of $10 \mathrm{mg}$ methallibure per $g$ dry food [6]. The treated food was mixed with tapwater to form a paste which was then placed in a $10 \mathrm{cc}$ plastic syringe. The paste was extruded from the syringe to form pellets containing approximately $0.3 \mathrm{mg}$ of methallibure. Each fish received one pellet daily in the morning. During the spawning trial the males were fed drugged or control food one hr before the morning observation. The females were fed frozen brine shrimp.

Testosterone enanthate (Schering AG, Berlin), a longlasting androgen, was injected intraperitoneally in sesame oil with a $100 \mu 1$ syringe and a 26 ga needle. Fish received $0.5 \mathrm{mg}$ testosterone enanthate in $10 \mu \mathrm{l}$ of oil.

\section{Spawning Trial}

Spawning was tested in 38 liter glass aquaria, filled to $25 \mathrm{~cm}$ with dechlorinated water. The walls adjacent to other tanks were covered with opaque white plastic to prevent subjects in different tanks from seeing each other. Tanks were drained and refilled with water before each spawning trial. Water temperatures were kept between 23 and $27^{\circ} \mathrm{C}$. The daily light period consisted of $14 \mathrm{hr}$ of fluorescent illumination directly above the aquaria. The water was undisturbed by filtration to facilitate foamnest building. Two plastic plants and a brick provided cover

The day before the spawning trial a ripe temale was placed in the tank and fed. The following morning the male was fed and placed in the tank. The pair remained together for five days or until spawning occurred. Spawning was considered to have occurred when eggs were seen in the nest. The proportion of males which spawned in each experimental group was recorded.

The fertility of the male was measured as the proportion of live eggs in a large sample of the brood 24 to $36 \mathrm{hr}$ following spawning. Eggs were removed after spawing appeared to be complete, incubated for 24 to $26 \mathrm{hr}$ and the number of live and dead eggs were counted. At the end of the trial the male was sacrificed and its body weight was measured. The testes or the remaining parts of testes were weighed to determine a posttrial GSI.

\section{Behavioral Observations}

The behavior of the males was observed during two daily 10 -min observation periods. The male was observed in the morning and the late afternoon until spawning took place or, if spawning did not occur, for five days. The pair was additionally checked every two to three hr to determine if nestbuilding, sexual curving or clasping sequences had begun. A curve was noted when the male curved its body around the female's abdomen. A clasp was recorded when the male successfully inverted the female $[16,21]$. In nestbuilding, the fish gulps air, descends below the surface and releases a stream of cohesive bubbles which accumulate in a foamy mass. The proportion of the males in each group that were seen to begin nestbuilding in the first $24 \mathrm{hr}$ of the trial was recorded.

\section{Procedure}

Eight groups of males were administered a five day spawning trial (Table 1). The males of Group 1 were placed in individual isolation tanks for 2 days prior to the trial. Group 2 was sham-operated 8 days prior to the spawning trial. Group 3 and 4 were castrated 8 days and 14 days prior to the spawning trial. The males of Groups 5 to 8 were administered $0.3 \mathrm{mg}$ of methallibure daily for eight days prior to and during the spawning trial. In addition to receiving methallibure, Group 5 was unoperated, Groups 6 and 8 were castrated eight days prior to the spawning trial, and Group 7 was castrated 14 days previously. Group 8 also received testosterone five days and one day prior to the spawning trial.

\section{RESULTS}

The results are presented in Table 1. There were overall significant differences between groups in spawning $\left(x^{2}=\right.$ 16.3, $d f=7, p<0.05$ ), fertility, $\mathrm{F}(7,30)=16.8, p<0.0001$ and nestbuilding $\left(x^{2}=58, d f=7, p<0.001\right)$. Posttrial GSI values differed between groups $F(4,46)=4.7, p<0.003$ but pretrial GSI values did not $F(4,35)=2.10, p<0.10$. The groups showed no change in body weight during the experiment.

\section{Effects of Castration}

The effects of castration on spawning one and two weeks postoperatively were evaluated by comparing the experimental groups to the control group using a test for 
TABLE 1

SPAWNING, NESTBUILDING, FERTILITY AND GONADOSOMATIC INDEX DATA

\begin{tabular}{lrcccc}
\hline \multicolumn{1}{c}{ Group } & N & $\begin{array}{c}\text { Spawned } \\
(\%)\end{array}$ & $\begin{array}{c}\text { Nestbuilding } \\
\text { within 24 hr } \\
(\%)\end{array}$ & $\begin{array}{c}\text { Fertility } \\
(\tilde{\mathrm{x}} \%)\end{array}$ & $\begin{array}{c}\text { G.S.I. } \\
(\tilde{\mathrm{x}})\end{array}$ \\
\hline $\begin{array}{l}\text { (1) intact males } \\
\text { (2) sham castrate }\end{array}$ & 12 & 75 & 100 & 90 & 0.160 \\
$\begin{array}{l}\text { 1 week } \\
\text { (3) castrated 1 week }\end{array}$ & 8 & 75 & 100 & 91 & - \\
(4) castrated 2 weeks & 11 & 45 & 91 & 34 & 0.010 \\
(5) intact males & 6 & 67 & 100 & 62 & 0.038 \\
$\begin{array}{l}\text { methallibure 1 week } \\
\text { (6) castrated 1 week } \\
\text { and methallibure }\end{array}$ & 8 & 88 & 87 & 88 & - \\
(7) castrated 2 weeks & 13 & 38 & 62 & 0.3 & 0.015 \\
$\begin{array}{l}\text { and methallibure } \\
\text { (8) castrated 1 week } \\
\text { methallibure and }\end{array}$ & 7 & 14 & 43 & 0 & 0.008 \\
testosterone & 14 & 79 & 64 & 11 & 0.012 \\
\hline
\end{tabular}

differences between two proportions [1]. Spawning was decreased at one week (Group 3, $p<0.05$ ) but not two weeks following surgery. The sham operation had no effect on reproduction.

Castration resulted in decreased fertility one and two weeks postoperatively $(p<0.001$, Scheffe $t$-test). The posttrial GSI of two-week castrates (Group 4) was four times greater than that of the one-week castrates in Group 3 $(p<0.0004)$. Analysis of differences between the proportions of males nestbuilding within $24 \mathrm{hr}$ showed no effect of castration.

\section{Effects of Methallibure and Testosterone}

Following administration of methallibure alone (Group $5)$, the proportion of males which began nestbuilding within $24 \mathrm{hr}$, the proportion which spawned, and fertility were unimpaired. In castrates, methallibure had timedependent effects. In males spawned one week following castration (Group 6), methallibure resulted in a significant decrease in fertility $(p<0.05$, Scheffe) and nestbuilding $(\mathrm{z}=2.52, p<0.01$ ), while spawning probability and the GSI were not decreased compared to undrugged castrates in Group 3. In two week castrates (Group 7), methallibure resulted in decreased spawning probability, in addition to decreased nestbuilding, fertility and GSI compared to the undrugged castrates in Group 4.

Testosterone administered to methallibure-treated, oneweek castrates (Group 8) resulted in an increased proportion of males spawning compared to Group $6(p<0.001)$. Spawning probability was in fact equivalent to that shown by the control group. Testosterone did not alter fertility, nestbuilding or the GSI.

\section{DISCUSSION}

The foregoing results suggest that gonadal androgen maintains sexual behavior in male Macropodus. Surgical removal of testicular tissue, the most direct procedure for reducing the level of endogenous androgens, results in only a temporary decrease in reproductive behavior and fertility.
While the decreased spawning seen one week following castration might be interpreted as a result of surgical trauma, the males which received the sham castration surgery showed normal spawning and fertility. Two weeks after castration, there is an increase in spawning, fertility and testicular tissue which can be blocked by prior administration of the antigonadotropin methallibure. When castrates receive methallibure and exogenous testosterone, spawning one week postoperatively is increased but fertility and the GSI are not. Since administration of testosterone counteracted the inhibitory effects of methallibure on spawning in castrated males, we infer that androgenic steroids participate in the activation of male sexual behavior in Macropodus. Postoperative application of antigonadotropin may make it possible to obtain a more complete blockade of testicular secretions than can be achieved by surgery alone.

The frequency of occurrence of nonsexual social behaviors was recorded during the daily observation periods. Male and female Macropodus both perform lateral and frontal displays, approach, bite-butt, and chase responses in bisexual and in unisexual encounters [5]. The mean frequencies of these responses did not vary significantly among the groups of males in this investigation and the data were omitted. Males show a higher frequency of lateral display than females do in a brief trial following a period of social isolation [4]. This sex difference suggests that in certain social situations lateral display may be facilitated by androgenic hormones.

Nestbuilding is sexually dimorphic in Macropodus. Males build nests in the spawning tank much more readily than females do. Neither castration nor testosterone replacement affected the latency to nestbuild. This suggests that decreased gonadal androgen secretion was not responsible for the decreased nestbuilding within $24 \mathrm{hr}$ in the methallibure treated castrates. Kramer $[17,18]$ found that both methallibure and the antiandrogen cyproterone acetate suppressed sexual behavior and nestbuilding in sunfish (Lepomis gibbosus). Machemer [21] reported that a dose of testosterone similar to that used in our experiment 
stimulates nestbuilding in intact male Macropodus, and that nestbuilding also depends on increased prolactin secretion. Testosterone influences nestbuilding in other fishes, such as sticklebacks and sunfish $[24,25]$.

Six experimental males ate some or all of their eggs. In our experience, egg eating is rare in intact males. One male each of Groups 3 and 6 , and four of the 14 males which received testosterone were seen to eat eggs from the nest during spawning. Egg viability did not seem to be a factor. Egg eaters usually took eggs immediately after spawning, and males which did not eat eggs were seen to guard nests of dead eggs. The implications of this unusual behavior are unclear.

Some males spawned even though the postmortem examination revealed no testicular tissue. Persistence of sexual behavior following castration has previously been observed in fishes [19] and is common in mammals [11]. It should be pointed out that Macropodus testes fragment or tear easily during surgery, and that minute remnants could escape detection. Such remnants may produce sufficient androgens to maintain sexual behavior, as Johns and Liley [14] proposed in their experiment in Trichogaster. Increased pituitary gonadotropin is reported to occur in castrated fish [26] and it might directly stimulate sexual behavior (cf. [19]). In our experiment, administration of a dose of methallibure which blocked testicular regeneration, and thus presumably suppressed gonadotropin release, did not prevent some castrates of Group 6 from spawning one week postoperatively. This suggests that the persistence of spawning was not owed to gonadotropin stimulation.

The antigonadotropic action of methallibure in fishes is well established. Prolonged administration of methallibure variously produced a reduction in gonad weight, atrophy of steroidogenic cells, and blocked gametogenesis in Carassuis, Gasterosteus, Cymatogaster, [12,28] Tilapia [13], Jenynsia [2], and Macropodus [6].. In unilaterally ovariectomized
Tilapia, postoperative administration of methallibure blocked the compensatory hypertrophy of the remaining ovary in two weeks [3]. Castrates may be more sensitive to methallibure than intact fish. Intact male and female Macropodus show no change in GSI or gametogenesis when methallibure is applied for less than two weeks [6]. In addition, the present experiment shows that a brief treatment with a dose of methallibure which does not noticeably effect reproductive functions in intact males, can result in decreased spawning, fertility, and GSI in castrated males.

The neural pathways by which sex steroids control reproductive behavior in fish have not been extensively investigated. Brain cells which concentrate estradiol and testosterone are restricted to areas of the ventral forebrain in Macropodus males [8]. The principal areas are the ventral telencephalon, the adjacent, rostral portion of the preoptic region, the posterior and inferior portions of the lateral tuberal nucleus, and the nucleus of the lateral recess proximal to ventricle III. Some of these brain areas are implicated in gonad function and sexual behavior by neural intervention experiments. Lesions selectively placed in the posterior portion of the lateral tuberal nucleus of Carassius result in gonad atrophy [22]. Electrical stimulation of the preoptic area of sunfish, Lepomis, evokes components of reproductive behavior including sperm release $[9,10]$ and preoptic lesions in killifish, Fundulus, interfere with elicitation of the spawning reflex [20]. In Macropodus, bilateral ablation of the telencephalon obliterates sexual and parental behavior in most males $[7,15,23]$. The ablation, which includes removal of varying portions of the rostral preoptic region, has little, if any, effect on nonsexual social behavior, feeding, and activity [.16]. The effects on reproductive behavior and gonad function of lesions restricted to individual sex steroid concentrating areas of the Macropodus brain are being investigated.

\section{REFERENCES}

1. Bruning, J. L. and B. L. Kintz. Computational Handbook of Statistics. Glenview: Scott, Foresman and Co., 1968.

2. Calvo, J. and E. Morriconi. Action of methallibure and exogenous gonadotropins on the testes of Jenynsia lineata (teleostei). Acta physiol. latinoam. 22: 212-217, 1972.

3. Dadzie, S. and M. Hyder. Compensatory hypertrophy of the remaining ovary and the effects of methallibure in the unilaterally ovariectomized Tilapia aurea. Gen. comp. Endocr. 29: 433-440, 1976

4. Davis, R. E., C. Harris and J. Shelby. Sex differences in aggressivity and the effects of social isolation in the anabantoid fish, Macropodus opercularis. Behav. Biol. 11: 497-509, 1974.

5. Davis, R. E. and J. Kassel. The ontogeny of agonistic behavior and the onset of sexual maturation in the paradise tish, Macropodus opercularis (Linnaeus). Behav. Biol. 14: 31-39, 1975.

6. Davis, R. E., M. Mitchell and L. Dolson. The effects of methallibure on conspecific visual reinforcement and social display frequency in the paradise fish, Macropodus opercularis (L.). Physiol. Behav. 17: 47-52, 1976.

7. Davis, R. E., J. Kassel and P. Schwagmeyer. Telencephaiic lesions and behavior in the teleost, Macropodus opercularis: Reproduction, startle reaction, and operant behavior in the maie. Behav. Biol. 18: 165-177, 1976.

8. Davis. R. E., J. I. Morrell and D. W. Pfaff. Estrogen and androgen concentrating cells in the brain of Macropodus opercularis (L.) (Osteichthyes: Belontiidae). Gen. comp. Endocr., in press.
9. Demski, L. S. and K. M. Knigge. The telencephalon and hypothalamus of the bluegill (Lepomis macrochirus): Evoke feeding, aggressive and reproductive behavior with representative frontal sections. J. comp. Neurol. 143: 1-16, 1971.

10. Demski, L. S., D. H. Bauer and J. W. Gerald. Sperm release evoked by electrical stimulation of the fish brain: A functional-anatomical study. J. exp. Zool. 191: 215-232, 1975.

11. Hart, B. L. Gonadal androgen and sociosexual behavior of male mammals: A comparative analysis. Psychol. Bull. 81: $383-400,1974$

12. Hoar, W. S., J. Wiebe and E. H. Wai. Inhibition of the pituitary gonadotropic activity of fishes by a dithiocarbamoylhydrazine derivative (ICI 33,828). Gen. comp. Endocr. 8: 101-109, 1967.

13. Hyder, M., A. V. Shah, C. M. Campbell and S. Dadzie. Methallibure studies on Tilapia. II. Effect of Tilapia pituitary homogenate (TPH), human chorionic gonadotropin (HCG) and testosterone proprionate (TP) on the testes of methallibure treated Tilapia niger. Gen. comp. Endocr. 23: 245-255, 1974

14. Johns, L. S. and N. R. Liley. The effects of gonadectomy and testosterone treatment on the reproductive behavior of the male blue gourami Trichogaster trichopterus. Can. J. Zool. 48: $977-987,1970$

15. Kassel, J., R. E. Davis and P. Schwagmeyer. Telencephaiic lesions and behavior in the teleost, Macropodus opercularis: Further analysis of reproductive and operant behavior in the male. Behav. Biol. 18: 179-188, 1976. 
16. Kassel, J. and R. E. Davis. Telencephalic lesions and behavior in the teleost, Macropodus opercularis: Effects of serial ablation and prior spawning on reproductive behavior. (In preparation).

17. Kramer, B. Behavioral effects of antigonadotropin, of sexual hormones, and of psychopharmaka in pumpkinseed sunfish. Lepomis gibbosus (Centrachidae). Experientia 28: 1195-1196, 1972.

18. Kramer, B. Chemische Wirkstoffe in Nestbau-, Sexual- and Kampiverhalten des Sonnenbarsches Lepomis gibbosus (L.) (Centrarchidae, Teleostei). Z. Tierpsychol. 32: 353-373, 1973.

19. Liley, N. R. Hormones and reproductive behavior in fishes. In: Fish Physiology edited by W. S. Hoar and D. J. Randall. New York: Academic Press, 1969.

20. Macey, N. J., G. E. Pickford and R. E. Peter. Forebrain localization of the spawning reflex response to exogenous neurohy pophysical hormones in the killifish, Fundulus hetero. clitus. J. exp. Zool. 190: 269-280, 1974.

21. Machemer, L. Synergistische Wirkung von Sauger-Prolacktin und Androgen beim Schaumnestbau des Paradiesfishes, Macropodus opercularis L. (Anabantidae). Z. Tierpsychol. 28: 33-53, 1971

22. Peter, R. E. Hypothalamic control of thyrojd gland activity and gonadal activity in the goldfish, Carassius auratus. Gen. comp. Endocrin. 14: 334-356, 1970.
23. Schwagmeyer, P., R. E. Davis and J. Kassel. Telencephalic lesions and behavior in the teleost, Macropodus opercularis: Effects of telencephalon and olfactory bulb ablation on spawning and foamnest building. (In preparation).

24. Smith, R. J. F. and W. S. Hoar. The effects of prolactin and testosterone on the parental behavior of the male stickleback Gasterosteus aculeatus. Anim. Behav. 15: 342-352. 1967.

25. Smith, R. J. F. Control of prespawning behavior of sunfish (Lepomis Gibbosus and $L$. megalotis). I. Gonadal Androgens. Anim. Behav. 17: 279-285, 1969.

26. Van den Hurk, $R$. and $H$. Van de Kant. The effect of methallibure and methyl testosterone on gonadotropic cells, Leydig cells and the intratesticular efferent duct system of the adult male black molly (Mollienisia latipinna). Proc. Kon. Ned. C. 78: $265-274,1975$.

27. Villars, T. and R. E. Davis. Suppression of spawning behavior in the male paradise fish (Macropodus opercularis (L.) following surgical castration and administration of methallibure. Anim. Behav. Soc. Meetings. Boulder: June 1976.

28. Wiebe, J. P. Inhibition of pituitary gonadotropic activity in the viviparous seaperch Cymatogaster aggregata Gibbons by a dithiocarbamoylhydrazone derivative (ICI 33,828). Can J. Zool. 46: 751, 1968.

29. Yamamoto, T. Sex differentiation. In: Fish Physiology, edited by W. S. Hoar and D. J. Randall. New York: Academic Press, 1969. 